Apidologie, 1988, 19 (4), 333-342

\title{
REACTION OF HONEYBEE WORKERS (APIS MELLIFERA L.) TO FATTY ACIDS IN QUEEN SIGNALS
}

\author{
Robin F.A MORITZ ${ }^{1}$, Robin M. CREWE ${ }^{2}$
}

1. Bayerische Landesanstalt für Bienenzucht, Burgbergstr. 70, 8520 Erlangen, Fed. Rep. Germany

2. Department of Zoology, University of the Witwatersrand, 1 Jan Smuts Ave. Johannesburg 2050, Rep. South Africa

\section{SUMMARY}

Honeybee workers (Apis mellifera) were tested in a metabolic bioassay for their response to the odours of semiochemicals of low volatility from the mandibular glands of queens and of chemically related compounds. (E)-9-oxodec-2-enoic acid, the queen substance (9-ODA) provided the most active volatile signal of the queen's mandibular gland secretions. Three other compounds tested did not release stronger reactions than related compounds not present in the queen signal. The workers reaction to 9$\mathrm{ODA}$ is as a result of olfaction and not of contact perception. The volatile signal of live queens released stronger reactions from the workers than mandibular gland extracts. Semiochemicals from sources other than the mandibular gland secretions seem to be responsible for this phenomenon.

\section{INTRODUCTION}

The fatty acid secretions of the mandibular glands of the queens are of striking importance for the regulation of behaviour and physiology in honeybees (Apis mellifera L.). Though (E) 9-oxo-2-decenoic acid (9-ODA) is believed to be the major active compound of the semiochemicals secreted in the mandibular glands (ButLER and FAIREY, 1964), a considerable number of other acids has been described with increasing accuracy of chemical analysis (PAIN $e t$ al., 1960 ; Crewe, 1982 ; Salovici, 1983).

Since most of these fatty acids are of low volatility, they are believed to operate within the hive as contact semiochemicals rather than as classical pheromones. Seeley (1979), Velthuis (1972) and Ferguson and Free (1980) have suggested that the queen signal is distributed by messenger workers within the hive rather than on the basis of its volatility. However, outside the hive, 9-ODA has repeatedly been shown to release behaviour as a result of its presence in the vapour phase. It attracts drones at mating congregation areas (GarY, 1962 ; Butler, 1971 ; RutTner, 1972) and it is crucial for the orientation of honeybees during swarming (AvitaBiLE et al., 1975 ; ВоCH and MoRSE, 1979). Some compounds in the mandibular gland secretions, are much more 
volatile than 9-ODA and might also be potential semiochemicals which could operate as airborne signals. These compounds, with a higher volatility than 9ODA, might release odour mediated behaviour in workers more effectively than 9-ODA itself.

In the present paper we study in a metabolic bioassay, previously used to quantify the reaction to alarm pheromones (Southwick and Moritz, 1985 ; Moritz et al., 1985) how worker bees react to the odours of queens, mandibular gland extracts, the fatty acids of the mandibular glands and chemically related compounds.

\section{MATERIALS AND METHODS}

\section{Metabolic bio-assay}

Groups of 50 honeybee workers (A. mellifera scutellata), at least seven days old, from a queenless colony were placed in ventilated airtight containers $(250 \mathrm{ml}$, flow rate $250 \mathrm{ml} / \mathrm{min})$ in the dark with candy ad libitum. In a flow through system previously described in detail (MoRIrz and Southwick, 1986) the oxygen concentration of the dried air which had passed over the worker group to be tested, was measured with an Ametek S3-AII oxygen analyzer. Before the air entered the bee container it passed through one of two small $10 \mathrm{ml}$ flasks in which the odour sources could be placed (Fig. 1). A T-valve allowed for switching between the two flasks and thus made differential testing between various odour sources possible. This set up allowed us to determine whether bees were able to discriminate between the compounds presented in the odour flasks.

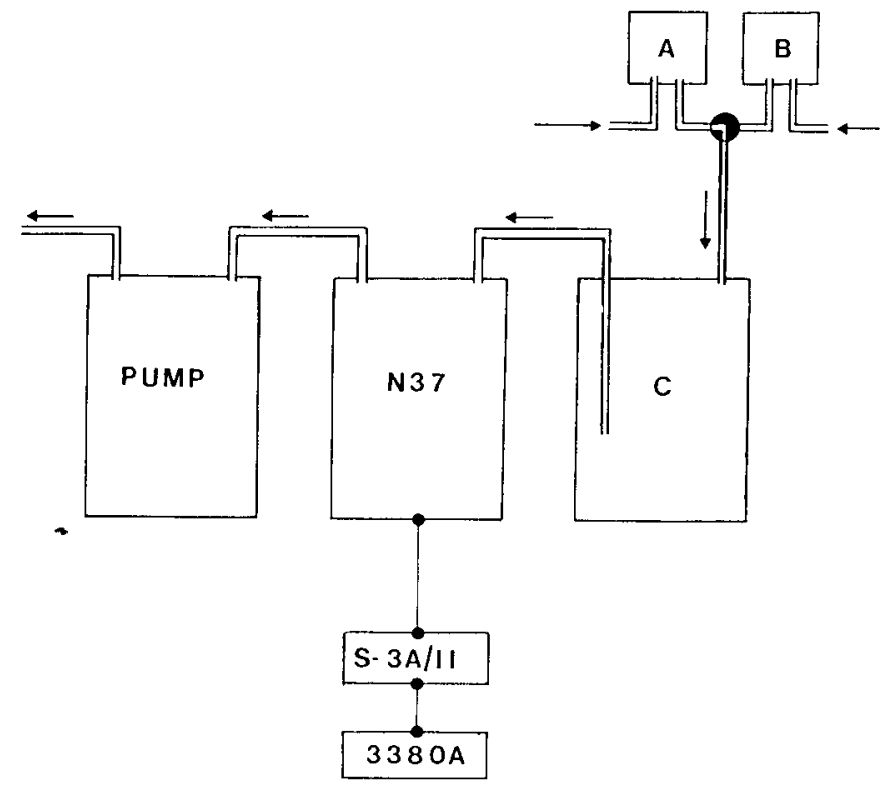

FIG. 1. - Diagram of experimental setup. A glass T-stopcock allowed for the selection of incoming air passing through either flask $A$ or $B$ which contained the various odour sources. The air was than led through the container $\mathrm{C}(250 \mathrm{ml})$ with the worker test group, dried, and pumped into an oxygen analyser (Ametek, SHI-A). The output signal, equivalent to the oxygen concentration in the air was recorded on an HP-3380A integrator. 


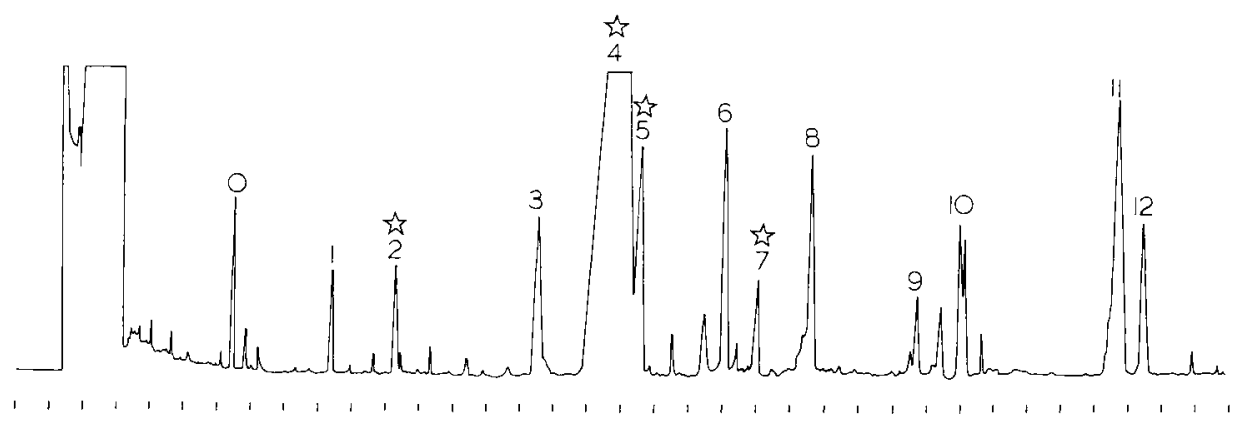

Fig. 2. - Chromatogram of the head extract of a queen. The asterisked peaks represent the compounds used in the bio-assay. The numbers represent the following compounds.

0: Octanoic acid (Internal Standard)

1: Tetradecane (Internal Standard)

2: Methyl-4-hydroxybenzoate (M-4-HB)

3: 8-hydroxyoctanoic acid

4: (E)-9-oxodec-2-enoic acid (9-ODA)

$5:$ 2-(4-hydroxy-3-methoxyphenyl)-ethanol (2-4-H-3MPE)

6: (E)-9-hydroxy-dec-2-enoic acid

7: 10-hydroxydecanoic acid (10-HDAA)

8: 2-(4-hydroxy-3-methoxyphenyl)-propanol

9: hexadecenoic acid

10 : hexadecanoic acid

11: octadecenoic acid

12: octadecanoic acid

\section{Synthetic compounds}

In order to determine whether bees are able to perceive the fatty acids in question, natural and chemically similar compounds were first tested at high concentrations. Fig. 2 shows a typical chromatogram of a queen tested in our experiments, with all the known compounds identified. The following four compounds, naturally appearing in the mandibular gland secretions, were used :

(E)-9-oxodec-2-enoic acid (9-ODA)

Methyl-4-hydroxybenzoate (M-4-HB)

2-(4-Hydroxy-3-methoxyphenyl)-ethanol (2-4-H-3-MPE)

10-Hydroxydecanoic acid (10-HDAA)

Furthermore synthetic compounds, which are similar to the above, but are not secreted by the queen's mandibular glands, were tested :

Hexadecanoic acid $=$ Palmitic acid $($ PA)

Octadecanoic acid $=$ Stearic acid (SA)

4-Hydroxybenzoic acid (4-HBA)

2-(4-Hydroxy-3-methoxyphenyl)-ethanol (2-4-H-2MPE)

In this set of experiments the test groups had to dicriminate between outside air and air with the odour of the compound. The test odours were obtained by saturating the air in a sealed vail with the compound at room temperature $\left(21^{\circ} \mathrm{C}\right)$. For testing, the vails were connected to the air inlet and the test group was exposed to the odour for 10 seconds and then again fresh air was led through the group. Each group was tested only once with each compound in random order, to avoid effects of conditioning or habituation. 
Queens and mandibular gland extracts

Queens from full size colonies were presented to the test groups as well as the extracts of the mandibular glands. For mandibular gland extractions, queens were decapitated and the heads placed in $200 \mu \mathrm{l}$ Dichloromethane. $180 \mu \mathrm{l}$ of the extract was placed on siliconized cover slips. After evaporation of the solvent these cover slips were used as an odour source in the experiments. The remaining volume was derivatized with bis-(trimethylsilyl) trifluoroacetamide (BSTFA) and analyzed with a capillary gas chromatograph (HP-5890, fitted with a $25 \mathrm{~m} \times 0.32 \mathrm{~mm}$ methyl silicone coated fused silica capillary column). Internal standards used in the analyses were octanoic acid and tetradecane. A split-splitless inlet was used to introduce the samples to the chromatograph and the carrier gas was hydrogen at a flow rate of $1.5 \mathrm{ml} / \mathrm{min}$. The oven temperature was programmed from $40^{\circ} \mathrm{C}$ to $100^{\circ} \mathrm{C}$ at $50^{\circ} \mathrm{C} / \mathrm{min}$ and from $100{ }^{\circ} \mathrm{C}$ to $220^{\circ} \mathrm{C}$ at $3{ }^{\circ} \mathrm{C} \mathrm{C} / \mathrm{min}$. From these analyses we determined the appropriate amounts for queen equivalents of 9-ODA, M-4-HB, 2-4-H-3-MPE and 10HDAA.

\section{Contact or olfactory perception?}

To clarify the manner in which 9-ODA functions in our bioassay : whether it is by contact or olfactory perception, 9-ODA samples ( $400 \mu \mathrm{g}$ on siliconized cover slips) were placed either directly in the test group or just presented as an odour source in the flask. Cover slips with plain solvent were introduced into the test groups as a control. 9-ODA samples placed in the bee-container were tested either versus fresh air on queen equivalents of 9-ODA. In addition, the responses of groups to the introduction of live queens or workers was measured.

\section{RESULTS}

\section{Response to synthetic compounds}

The test groups responded to all compounds presented and were able to discriminate these from fresh air. The test groups generally increased their metabolic activity after being exposed to the odour (Fig. 3). The reaction to 9ODA was stronger than to any other synthetic compound tested (Tabl. 1). An analysis of variance among the reactions to the various compounds including 9ODA reveals a highly significant effect of the compound on the reaction $(\mathrm{F}=2.5, \mathrm{p}<0.05)$. If the 9-ODA data is excluded from the analysis, there is no significant effect of the compound on the reaction of the test groups ( $F=1$, not significant). Thus the other compounds of the mandibular gland secretions tested, did not elicit stronger reactions than the chemically similar synthetic compounds that are not synthesized by the bees.

\section{Reactions to queens, gland extracts and physiological amounts of synthetic compounds}

The test groups responded most strongly $\left(33.1 \pm 3.2 \mu \mathrm{l} 0_{2} / \mathrm{bee} / \mathrm{min}\right)$ when they were exposed to the odour of living queens. Physiological amounts (queen equivalents) of 9-ODA $(400 \mu \mathrm{g})$ or M-4-HB $(50 \mu \mathrm{g})$ elicited significantly smaller reactions than mandibular gland extracts (Tabl. 2). The test groups never responded to physiological doses of 10-HDA $(50 \mu \mathrm{g})$ or 2-4-H-3-MPE $(50 \mu \mathrm{g})$. 


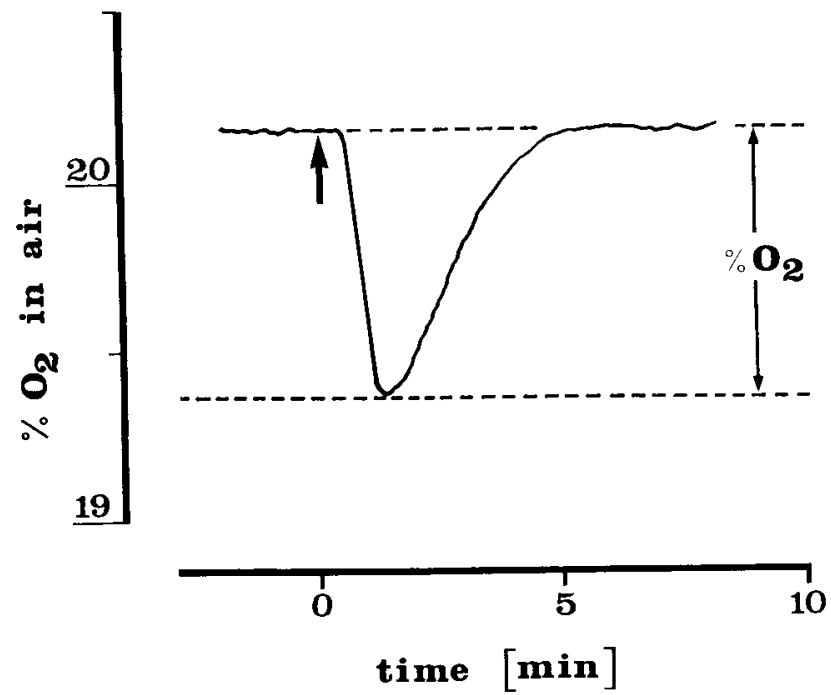

Fig. 3. - Typical reaction of a group of worker honeybees after 10 sec exposure to the odour of the compound.

TABL. 1. - Average reaction $\pm S E\left(\mu l \mathrm{O}_{2} /\right.$ bee/min) of worker groups which were exposed to air with the compound tested for $10 \mathrm{sec}$

\begin{tabular}{|c|c|c|c|c|c|}
\hline \multicolumn{2}{|l|}{ Compound } & Reaction & \multicolumn{2}{|l|}{$\mathrm{SE}$} & $\mathbf{n}$ \\
\hline \multicolumn{2}{|l|}{ 9-ODA } & 17.08 & \multicolumn{2}{|l|}{1.37} & 14 \\
\hline \multicolumn{2}{|l|}{ M-4-HB } & 9.95 & \multicolumn{2}{|l|}{6.15} & 7 \\
\hline \multicolumn{2}{|l|}{ 10-HDA } & 7.62 & \multicolumn{2}{|l|}{4.26} & 6 \\
\hline \multicolumn{2}{|l|}{ 2-4-H-3-MPE } & 11.25 & \multicolumn{2}{|l|}{2.76} & 6 \\
\hline \multicolumn{2}{|l|}{ PA } & 3.55 & \multicolumn{2}{|l|}{2.72} & 8 \\
\hline \multicolumn{2}{|l|}{ SA } & 8.25 & \multicolumn{2}{|l|}{2.83} & 6 \\
\hline \multicolumn{2}{|l|}{ 4-HB } & 12.96 & \multicolumn{2}{|l|}{3.21} & 7 \\
\hline \multicolumn{2}{|l|}{ 2-4-H-2MPE } & 4.50 & \multicolumn{2}{|l|}{3.86} & 7 \\
\hline \multicolumn{3}{|c|}{ Anova including 9-ODA } & \multicolumn{3}{|c|}{ Anova excluding 9-ODA } \\
\hline Source of variance & DF & Sum of Squares & Source of variance & DF & Sum of Squares \\
\hline Odour & 7 & 1240.4 & Odour & 6 & 501.8 \\
\hline Error & 53 & 3708.9 & Error & 46 & 3372.7 \\
\hline Total & 60 & 4949.3 & Total & 52 & 3874.5 \\
\hline \multicolumn{3}{|l|}{$\mathrm{F}=2.53, \mathrm{p}<0.05$} & \multicolumn{3}{|l|}{$F=0.99$, not signific } \\
\hline
\end{tabular}


TABL. 2. - Average reaction $\pm S E(\mu l /$ bee/min) of worker groups to queen equivalents of mandibular gland secretions, mandibular gland extracts and odours of live queens.

\begin{tabular}{l|c|c|c}
\hline \multicolumn{1}{c|}{ Odour source } & Reaction & SE & $\mathbf{n}$ \\
\hline 9-ODA & 15.9 & 2.21 & 10 \\
M-4-HB & 7.2 & 4.22 & 8 \\
2-4-H-3-MPE & 0 & 0 & 7 \\
10 HDA & 0 & 0 & 7 \\
Gland extract & 24.3 & 4.67 & 5 \\
Queen & 33.1 & 7.43 & 8 \\
\hline \hline
\end{tabular}

TABL. 3. - Average reaction of worker groups to a $10 \mathrm{sec}$ exposure to the odours of mandibular gland extracts, queens and synthetic compounds (queen equivalents) while being constantly exposed to one queen equivalent of synthetic 9-ODA

\begin{tabular}{l|l|l|l}
\hline \multicolumn{1}{c|}{ Odour source } & Reaction & SE & $\mathrm{n}$ \\
\hline Room air & 0 & 0 & 7 \\
M-4-HB & 6.75 & 1.38 & 8 \\
4-HB & 4.20 & 1.39 & 7 \\
Gland extract & 11.25 & 2.73 & 6 \\
Queen & 15.30 & 4.51 & 8 \\
\hline
\end{tabular}

In another set of experiments the bees were tested while being constantly exposed to a queen equivalent of 9-ODA instead of fresh air (Tabl. 3). Again the bees responded strongly to the odour of queens or mandibular gland extracts, but only weakly to queen equivalents of M-4-HB or similar amounts of 4-HB. An analysis of variance reveals significant effects of the compound on the group reaction $(\mathrm{F}=8.9, \mathrm{p}<0.001)$.

\section{Reactions to samples in the test container}

The test groups responded as strongly to 9-ODA samples placed directly in the test container $(19.2 \pm 4.4 \mu \mathrm{l} / \mathrm{bee} / \mathrm{min})$ as to samples placed in the odour flasks $(18.5 \pm 7.5 \mu \mathrm{l} / \mathrm{bee} / \mathrm{min} ; \mathrm{t}=0.08$, n.s. $)$. If the bees were constantly exposed to 9-ODA, the reaction to 9-ODA treated cover slips was not significantly stronger than to untreated cover slips. When live queens were introduced directly into the test group, the metabolic reaction was about twice as strong as that to the queen's odor alone. Even in the presence of 9-ODA, the introduction of a queen into the group elicited a strong reaction. The test groups did not respond to the introduction of workers of the same colony (Tabl. 4). 
TABL. 4. - Reactions ( $\mu$ l/bee/min) to samples placed directly into the test group while being exposed to fresh air (AIR) or a queen equivalent of 9-ODA.

\begin{tabular}{l|c|r|r|r|r|c}
\hline \hline \multirow{2}{*}{ Sample } & \multicolumn{3}{|c|}{ Air } & \multicolumn{3}{c}{$9-$ ODA } \\
\cline { 2 - 7 } & Reaction & SE & $\mathbf{n}$ & Reaction & SE & $\mathbf{n}$ \\
\hline Control & 1.0 & 0.8 & 4 & 0.9 & 0.7 & 4 \\
$9-$-ODA & 18.5 & 7.5 & 5 & 2.3 & 1.5 & 5 \\
Oueen & 88.1 & 19.3 & 5 & 23.4 & 2.1 & 5 \\
Worker & 1.2 & 0.9 & 5 & 1.9 & 1.0 & 5 \\
\hline \hline
\end{tabular}

Control = plain cover slide, 9-ODA $=$ cover slide $400 \mu \mathrm{g}$ 9-ODA, queen $=$ one living queen, worker $=$ one worker from the same hive as the test group.

\section{DISCUSSION}

In the present study we have shown that worker bees are able to perceive the odours of compounds of low volatility secreted by the queen's mandibular glands and compounds chemically related to them. The reaction to 9-ODA is strikingly different from that of the other compounds tested. Only 9-ODA released a reaction similar to that of the odour of queens or mandibular gland extracts. Since the test bees were in an enclosed environment this shows that 9-ODA, in spite of its low volatility, may act as a volatile semiochemical cue in this context as well as during swarming or mating. The other compounds that were not particularly active in our bioassay could be distributed by messenger workers (SEeley, 1979) and perceived by contact perception. Such a mechanism has also been suggested by VerheIJEN-Voogd (1959) and Vecthuis (1972, 1985).

Though the bees reacted strongly to 9-ODA samples, our results show that there is more to a queen's mandibular glands signal than just 9-ODA. The responses to the odours of mandibular gland extracts in the presence of equivalent amounts of 9-ODA clearly confirm this. Which of the components of the mandibular gland secretion are important semiochemicals remains unclear since many of the compounds were not available for testing in this study. Apparently neither 10-HDA nor 2-4-H-3-MPE seem to be of major importance for the metabolic reaction to mandibular gland extracts, since the bees did not respond to these compounds in the presence of 9-ODA. M-4-HB might be a good candidate, particularly in the light of its relatively high volatility (see chromatogram in Fig. 2). Bees generally responded to the odour of M-4-HB, even in the presence of 9-ODA. However, since many compounds 
are involved in the composition of the mandibular gland signal, it may well be that the composition itself is the key to the reactions of the bees, rather than single compounds as recently proposed by SLeSSOR et al. (1988).

The queens in all cases released the strongest reaction, indicating that there are important signals other that the mandibular gland secretions. Good candidates for such semiochemicals are probably the tergal gland secretions, first mentioned by RENNER and BAUMANN (1964) and experimentally tested by Velthuis (1972) and VierLing and RenNer (1977). Since these compounds are attractive to drones during mating (RENNER and VIERLING, 1977), they are believed to be fairly volatile. Indeed it is volatile signals that are those most effective in the present bioassay, where the reaction of honeybee workers to odours are tested.

Queens placed directly into a queenless group of workers elcit a much stronger reaction than the presentation of just the queen's odours (MoRITz and Southwick, 1986). However it is difficult to conclude from this phenomenon, whether it results from a simple dose effect or true contact perception. Our results indicate that 9-ODA, is not involved in this phenomenon, since reactions to 9-ODA samples were similar when presented within the test container or in the odour flask. 9-ODA, in spite of its low volatility, seems to be mainly effective as an olfactory semiochemical in the metabolic bioassay. Our results confirm that it seems to be the most powerful semiochemical of the bouquet of the queens mandibular gland secretion.

Received for publication in March 1988. Accepted for publication in May 1988.

\section{ACKNOWLEDGEMENT}

We wish to thank the CSIR and the University of the Witwatersrand (R.M.C. and R.F.A.M.), the Deutsche Forschungsgemeinschaft (R.F.A.M.), and the Bayerisches Staatsministerium für Ernährung, Landwirtschaft und Forsten for financially supporting our studies.

\section{RÉSUMÉ}

RÉACTION DES OUVRIÈRES D'ABEILLES (APIS MELLIFICA L.) AUX ACIDES GRAS PRÉSENTS DANS LES SIGNAUX DE LA REINE

La réaction des ouvrières à l'odeur des médiateurs chimiques des glandes mandibulaires de la reine (Fig. 2) a été étudiée par un test de métabolisme (Fig. 1, 3). Parmi les substances testées, c'est l'odeur de l'acide céto-9 décène-2 oïque (la substance royale : 9-ODA) qui a déclenché la plus forte réaction métabolique dans tous les tests (Tabl. 1,2,4). Les abeilles n'ont pas réagi plus fortement à trois autres composés des glandes mandibulaires (M-4-HB ; 10-HDA ; 2-4-H-3-MPE) qu'à des substances chimiquement semblables mais non sécrétées par la reine (Tabl. 1). La réaction métabolique des ouvrières est due 
à l'olfaction et non à la chimioréception de contact. Les abeilles n'ont pas réagi aux substances testées lorsqu'elles étaient exposées à l'odeur d'un équivalent-abeille de 9-ODA (Tabl. 4). Dans tous les cas, la réaction à l'odeur de reine vivante a été la plus forte (Tabl. 2, 3,4). Des médiateurs chimiques autres que la phéromone royale doivent jouer un rôle important dans la reconnaissance de la reine. Les extraits de sécrétions des glandes mandibulaires ont déclenché, lors du test de métabolisme, des réactions plus faibles que les reines vivantes (Tabl. 2, 3, 4).

\section{ZUSAMMENFASSUNG}

\section{REAKTIONEN VON ARBEITERINNEN (APIS MELLIFERA L.) AUF FETTSÄUREN IN KÖNIGINNENSIGNALEN}

Die Reaktion von Arbeiterinnen auf den Duft von Semiochemikalien der Königinnen-Mandibulardrüsen (Abb. 2) wurde in einem Stoffwechseltest (Abb. 1, 3) dargestellt. Von den getesteten Stoffen löste der Duft der 9-Oxodecensäure (9-ODA, die klassische Königinnensubstanz) in allen Tests die stärkste Stoffwechselreaktion aus (Tab. 1, 2, 4). Auf drei andere Mandibulardrüsensekrete (M-4-HB ; 10-HDA ; 2-4-H-3-MPE) reagierten die Bienen nicht stärker als auf chemisch ähnliche Substanzen, die nicht von der Königin sezerniert werden (Tab. 1). Die Stoffwechselreaktion der Arbeiterinnen resultiert hauptsächlich aus olfaktorischer und nicht aus Kontaktperzeption. Die Bienen reagierten nicht auf Testsubstanzen, wenn sie einem Königinnenequivalent des Duftes von 9-ODA ausgesetzt waren (Tab. 4). In allen Fällen war die Reaktion auf den Duft lebendiger Königinnen am stärksten (Tab. 2, 3, 4). Außer den klassischen Königinnenphermonen, spielen noch andere Semiochemikalien eine wesentliche Rolle bei der Königinnenerkennung. Extrakte der Mandibulardrüsensekrete im Stoffwechseltest lösten schwächere Reaktionen als lebendige Königinnen aus (Tab. 2, 3).

\section{REFERENCES}

Avitabile A., Morse R.A., Boch R., 1975, - Swarming honeybees guided by pheromones. Ann. entomol. Soc. Am., 68, 1079-1082.

Boch R., Morse R.A., 1979. - Individual recognition of queens by honeybee swarms. Ann. entomol. Soc. Am., 72, 51-53.

Butler C.G., 1971. - The mating behaviour of the honeybee (Apis mellifera L.). J. Entomol., 46, 1-11.

Butler C.G., Fairey E.M., 1964. - Pheromones of the honeybee : biological studies of the mandibular gland secretion of the queen. $J$. apic. Res., 3, 65-76.

Crewe R.M., 1982. - Compositional variability : the key to the social signals produced by honey bee mandibular glands. In : Breed M.D., Michener C.D., Evans H.E. (eds) The Biology of Social Insects. Westview Press, Boulder, 318-322.

Ferguson A.W., Free J.B., 1980. - Queen pheromone transfer within honeybee colonies. Physiol. Entomol., 5, 539-366.

GARY N.E., 1962. - Chemical mating attractants in the queen honeybee. Science 136, 773-774.

Moritz R.F.A., Southwick E.E., BreH M., 1985. - A metabolic test for the quantitative analysis of alarm behaviour of honey bees. J. Exp. Zool., 235, 1-5.

Moritz R.F.A., Southwick E.E., 1986. - Analysis of queen recognition by honey bee workers (Apis mellifera L.) in a metabolic bioassay. Exp. Biol., 46, 45-49.

Pain J., Hugel M.F., Barbier M., 1980. - Sur les constituents du mélange attractif des glandes mandibulaires des reines d'abeilles. C.R. Acad. Sci. (Paris), 254, 1046-1048. 
Renner M., Baumann M., 1964. - Über Komplexe von subepidermalen Drüsenzellen (Duftdrüsen ?) der Bienenkönigin. Naturwissenschaften, 51, 68-69.

Renner M., Vierling G., 1977. - Die Rolle des Taschendrüsenpheromons beim Hochzeitsflug der Bienenkönigin. Behav. Ecol. Sociobiol., 2, 329-338.

RutTNer H., RutTNer F., 1972. - Untersuchungen über die Flugaktivität und das Paarungsverhalten der Drohnen. Apidologie, 3, 203-232.

SAIOvicI M., 1983. - 9-Oxodecenoic acid and dominance in honeybees. J. apic. Res., 22, 27-32.

SEelEy T.D., 1979. - Queen substance dispersal by messenger workers in honeybee colonies. Behav. Ecol. Sociobiol., 5, 391-415.

Slessor K.N., Kaminski L.-A., King G.G.S., Borden J.H., Winston M.L., 1988. - Semiochemical basis of the retinue response to queen honey bees. Nature, 332, 354-356.

Southwick E.E., Morriz R.F.A., 1985. - Metabolic response to alarm pheromone in honeybees. $J$. Insect Physiol., 31, 389-392.

Velthuis H.H.W., 1972. - Observations on the transmission of queen substances in the honeybee colony by the attendants of the queen. Behaviour, 41, 105-129.

Velthuis H.H.W., 1985. - The honeybees queen and the social organization of her colony. In : Experimental Behavioral Ecology and Sociobiology. Eds. Hölldobler B., Lindauer M., Gustav Fischer Verlag, Stuttgart, pp. 343-357.

VerHejen-Voogd C., 1959. - How worker bees perceive the presence of their queen. $Z$. vergl. Physiol., 41, 527-582.

Vierling G., Renner M., 1977. - Die Bedeutung des Sekretes der Tergittaschendrüsen für die Attraktivität der Bienenkönigin gegenüber jungen Arbeiterinnen. Behav. Ecol. Sociobiol., 2, 185200 . 